OPEN ACCESS

Citation: Cedeño-Fonseca M. et al. (2020) Two new endemic species of Monstera (Araceae: Monsteroideae: Monstereae) from Golfito in southern Costa Rica. Webbia. Journal of Plant Taxonomy and Geography 75(1): 123-132. doi: 10.36253/jopt-8091

Received: February 14, 2020

Accepted: March 18, 2020

Published: June 30, 2020

Copyright: (C) 2020 Marco CedeñoFonseca, Alistair Hay, Michael H. Grayum, Mario A. Blanco. This is an open access, peer-reviewed article published by Firenze University Press (http:// www.fupress.com/webbia) and distributed under the terms of the Creative Commons Attribution License, which permits unrestricted use, distribution, and reproduction in any medium, provided the original author and source are credited.

Data Availability Statement: All relevant data are within the paper and its Supporting Information files.

Competing Interests: The Author(s) declare(s) no conflict of interest.

Editor: Peter C. Boyce

\section{Two new endemic species of Monstera (Araceae: Monsteroideae: Monstereae) from Golfito in southern Costa Rica}

\author{
Marco Cedeño-Fonseca ${ }^{1, *}$, Alistair Hay $^{2}$, Michael H. Grayum ${ }^{3}$, Mario \\ A. BLANCO ${ }^{1,4,5}$ \\ ${ }^{1}$ Programa de Posgrado en Biología / Herbario Luis Fournier Origgi (USJ), Universidad \\ de Costa Rica, San José, Costa Rica \\ ${ }^{2}$ Royal Botanic Gardens, Mrs Macquarie’s Road, Sydney 2000, Australia \\ ${ }^{3}$ Missouri Botanical Garden, 4344 Shaw Blvd., St. Louis, MO 63110, USA \\ ${ }^{4}$ Jardín Botánico Lankester, Universidad de Costa Rica, P. O. Box 302-7050 Cartago, Cos- \\ ta Rica \\ ${ }^{5}$ Escuela de Biología and Centro de Investigación en Biodiversidad y Ecología Tropical, \\ Universidad de Costa Rica, 11501-2060 San José, Costa Rica \\ ${ }^{*}$ Corresponding author. E-mail: marcovf.09@gmail.com
}

\begin{abstract}
Monstera croatii M.Cedeño \& A.Hay and M. gambensis M.Cedeño \& M.A.Blanco (Araceae: Monsteroideae: Monstereae) are newly described and illustrated from cantón Golfito in the Pacific lowlands of southern Costa Rica. Notes are provided on how they can be differentiated from similar species. Monstera croatii is unique in the genus because it reaches its adult vegetative morphology while growing as a terrestrial plant on the forest floor, and climbs only to a very limited height before flowering. Monstera gambensis is one of the smallest species in the genus.
\end{abstract}

Keywords: Aroids, Central America, Osa Peninsula.

\section{INTRODUCTION}

In Costa Rica there are some 24 genera and 256 species of Araceae (including subfamily Lemnoideae, commonly treated as a separate family), the most well-represented of the genera being Anthurium Schott, Philodendron Schott, and Monstera Adans. (Grayum 2003; Ortiz et al. 2018). These groups are abundant and diverse in very humid lowland forests and in cloud forests (Grayum 2003). Monstera is a genus that consists mostly of nomadic vines (sometimes referred to as hemi-epiphytes, but see Zotz 2013), and is best known for its often conspicuously perforated leaves (Grayum 2003; CedeñoFonseca et al. 2018; Hay 2019). Molecular-phylogenetic analyses of subfamily Monsteroideae agree in finding Monstera to be a monophyletic genus most closely allied to the tropical Asian genus Amydrium Schott and some (but not all) species of the likewise Asian Epipremnum Schott, and it is the only neotropical member of the pantropical tribe Monstereae or 'Rhaphidophora 
clade' (Tam et al. 2004; Zuluaga et al. 2019). It is considered one of the taxonomically most poorly understood aroid groups in Mesoamerica (Madison 1977; Croat 1992; Jácome and Croat 2002; Grayum 2003). The most recent taxonomic revision (Madison 1977) recognized 22 species in the entire genus. However, the first author's current research, revising Monstera for Central America, indicates that there are more than 40 species in this region alone (Cedeño-Fonseca 2019), with an as yet undetermined number of further species from Mexico, tropical South America, and the Caribbean.

The genus is currently divided into four sections - Echinospadix Madison, Marcgraviopsis Madison, Tornelia (Gutiérrez ex Schott) Madison, and Monstera (Madison 1977; Mayo et al. 1997; Croat et al. 2010) though it is doubtful whether this infrageneric classification will stand up to molecular analysis (e.g., Zuluaga et al. 2019). Section Monstera includes, among others, several small, mainly South American species - Monstera obliqua Miq. (Costa Rica to Ecuador, Perú, Venezuela, the Guianas and Brazil), M. xanthospatha Madison (western Colombia), and M. minima Madison (Panama and Colombia) (Madison 1977; Jácome and Croat 2002) - and during recent fieldwork in the forests of $\mathrm{La}$ Gamba, Golfito, a new diminutive species was collected, which is described and illustrated here. In addition, a species with terrestrial (or near terrestrial) habit was also collected in Golfito, which only ascends on the phorophyte to about $1.5 \mathrm{~m}$ above ground level. This species has also proven to be undescribed, and is named here. It too belongs to sect. Monstera sensu Madison (1977).

\section{Monstera croatii M.Cedeño \& A.Hay, sp. nov.}

Type: Costa Rica, Puntarenas Province, Golfito Canton, Golfito, camino hacia las antenas, $8^{\circ} 38^{\prime} 55.1^{\prime \prime} \mathrm{N}$, $83^{\circ} 9^{\prime} 30.8^{\prime \prime} \mathrm{W}, 389$ m, 4 February 2019 (fr.), M. Cedeño \& A. Hay 1624 (holotype: USJ [2 sheets]). (Figures 1, 2).

\section{Diagnosis}

Monstera croatii is recognized by its terrestrial or very low nomadic-vining habit, petioles glaucous at the base, with the sheath extending to about half the total length, the sheath margins involute, and the free portion terete, greyish-glaucous leaf blades, adult leaf blades deeply pinnatifid, peduncles with a persistent mucronate cataphyll, and spadices with more or less spherical basal sterile flowers.

\section{Description}

Moderately robust terrestrial herb to appressed nomadic vine, flowering at ca. 0.5-1.5 m above ground level. Seed- lings not observed. Juvenile plants terrestrial; stem pale to dark green, smooth, terete, with internodes $1-2.4 \mathrm{~cm}$ long by $0.5-1 \mathrm{~cm}$ diam.; petioles visible (i.e., the blades not shingling), pale to dark green, smooth, $8-10 \mathrm{~cm}$ long, sheathed in the lower $3-6 \mathrm{~cm}$, the wings persistent, above the sheath more or less terete to slightly channeled; leaf blades not appressed to the substrate, 10-20 $\times 4-10 \mathrm{~cm}$, lanceolate, narrowed to the base, acuminate at the apex, thinly coriaceous, with or without fenestrations and if fenestrate then generally on only one side and breaking at the margin. Adult plants terrestrial and eventually becoming appressed-climbing before flowering; stem dark green to pale brown, terete, the internodes $1-1.5 \mathrm{~cm}$ long, $1.5-2 \mathrm{~cm}$ diam., with pale brownhairy support and feeder roots; petioles rather pale bluish green, glaucous/pruinose, smooth, $34-45 \mathrm{~cm}$ long, sheathed in the lower $20-28 \mathrm{~cm}$, with the wings persistent and involute, the free portion terete, slightly canaliculate near the geniculum; geniculum more or less terete, very slightly canaliculate adaxially, 2-2.5 $\mathrm{cm}$ long; leaf blades $30-45 \times 25-33 \mathrm{~cm}$, oblong-ovate, rounded to asymmetric at the base, shortly acuminate at the apex, subcoriaceous, deeply pinnatifid but not fenestrate, not decurrent onto the geniculum, glaucous abaxially, the anterior costa canaliculate adaxially, convex abaxially, primary lateral veins $8-13$ per side, adaxially impressed, abaxially prominent; secondary and tertiary venation parallel; collective vein visible at the margins of each lobe; lobes $6-12$ per side, $0.5-2.5 \mathrm{~cm}$ wide, with 1 or 2 primary veins each, sometimes distally bifid. Inflorescences on ascending shoots, 1-2 per flowering episode, subtended by basally sheathing, greenish, distally 3-keeled, apically mucronate, persistent cataphylls; peduncle smooth, 20-25 cm long; spathe acuminate, with two longitudinal keels, membranaceous, light green at pre-anthesis, white-yellowish externally and white internally at anthesis, marcescent after the anthesis, 9-14 $\times$ 3-5 $\mathrm{cm}$; spadix white in pre-anthesis and anthesis, 6-8 $\times 2.5-3 \mathrm{~cm}$ in early fruit, the basal zone of sterile flowers slender, very conspicuous; sterile flowers 3-5 mm long, round with a very prominent stigmatophore; fertile flowers 5-6 mm long; stamens with laminar filaments 2-5 mm long; anthers 1-2 $\mathrm{mm}$ de long; ovary squareprismatic, $1.5-3 \times 1.5-2 \mathrm{~mm}$; style squarish, rounded or hexagonal, $0.5-1 \times 2-3 \mathrm{~mm}$; stigma linear. Infructescence with the stylar caps green after anthesis; mature fruits not observed; seeds not observed.

\section{Etymology}

The new species is named for Dr. Thomas B. Croat (MO), the leading authority on neotropical Araceae. He also realized that some herbarium specimens of this spe- 


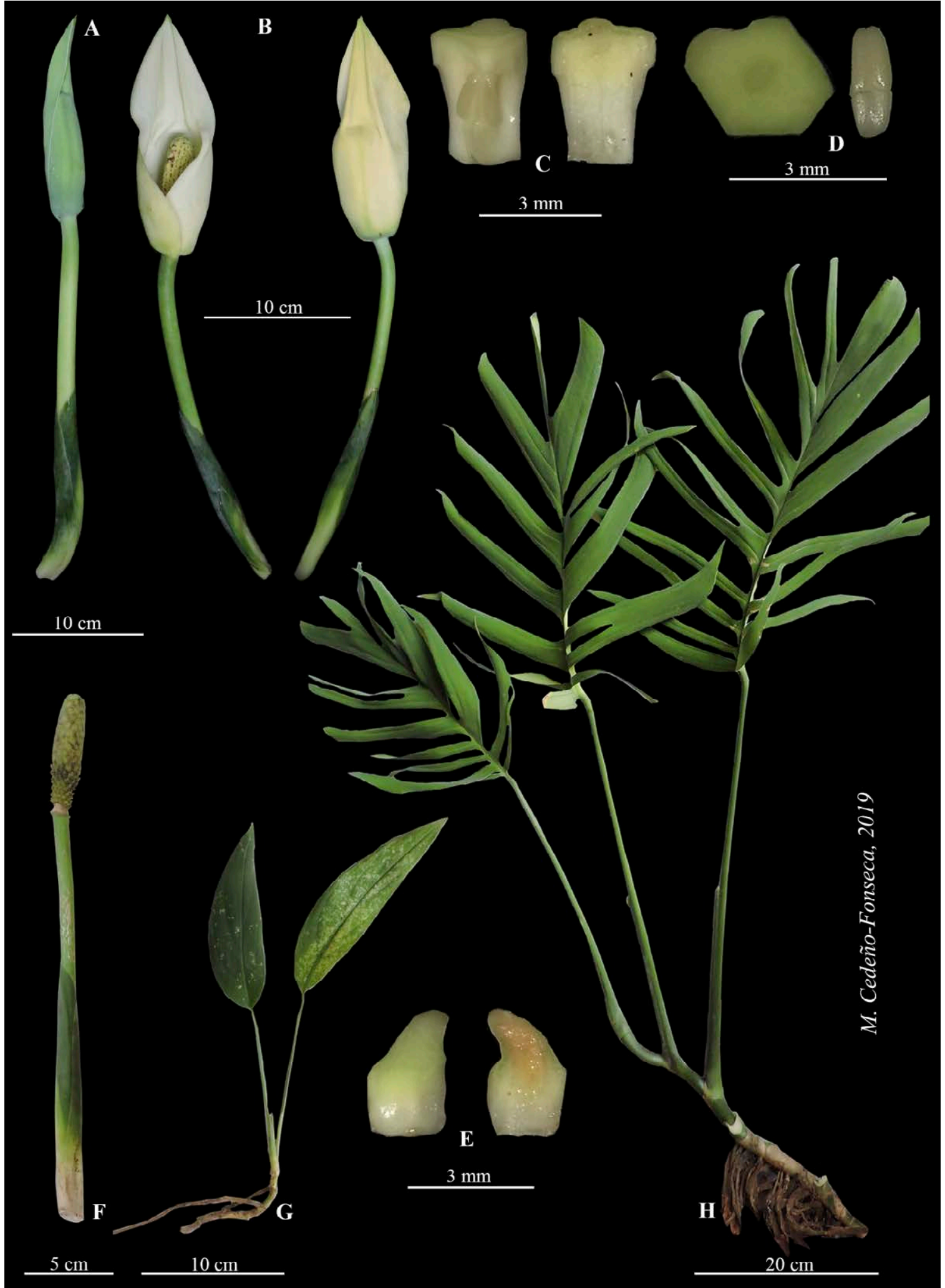

Figure 1. Monstera croatii. A. Developing inflorescence. B. Front and back views of open inflorescence. C. Fertile flower in lateral view (left) and in longitudinal section (right). D. Stylar plate, top view (left), and individual stamen (right). E. Sterile flower in lateral view (left) and in longitudinal section (right). F. Infructescence. G. Juvenile plant. H. Adult plant. 

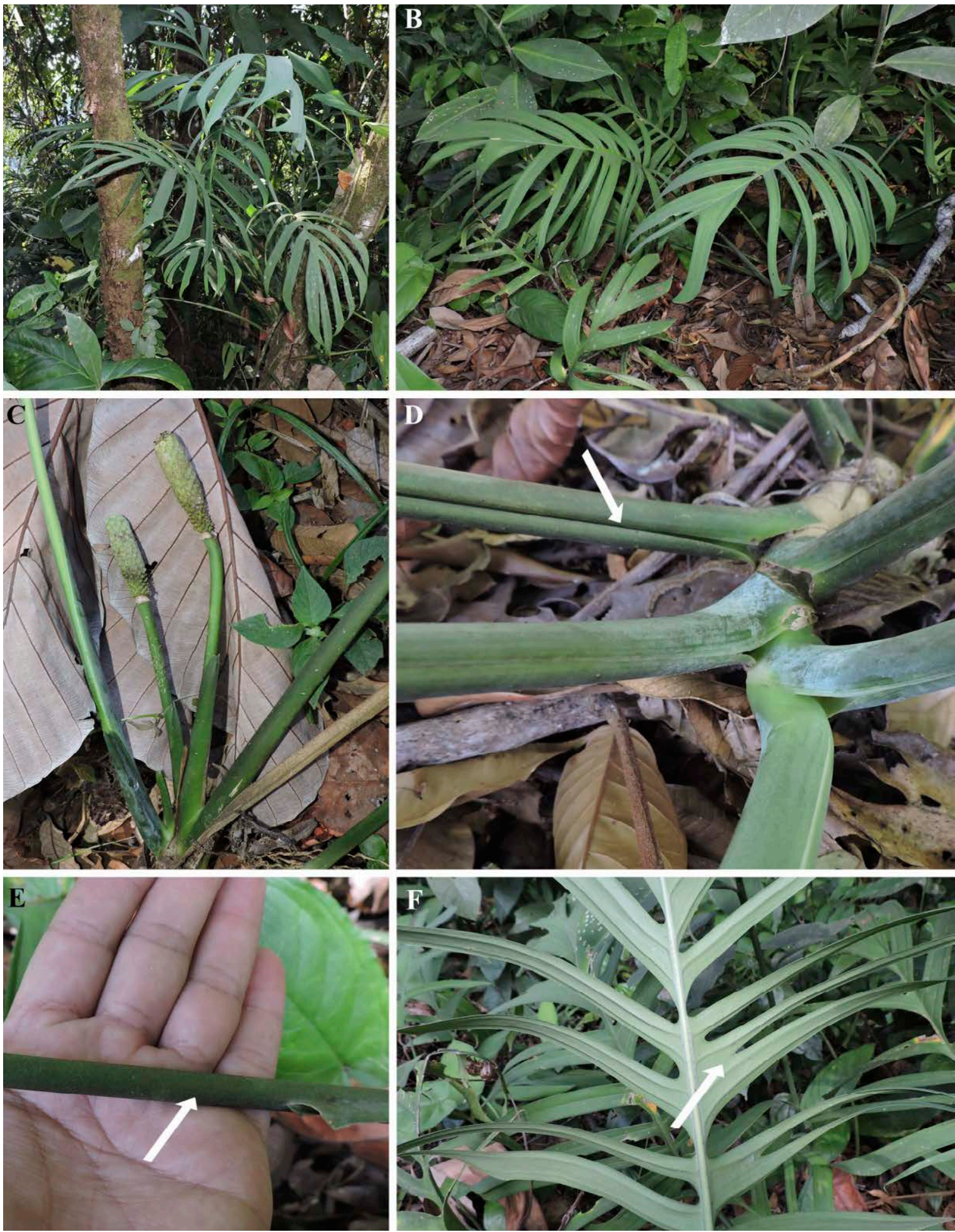

Figure 2. Adult plant of Monstera croatii (see description for dimensions). A. Hemi-epiphytic habit, ascending to only $1.5 \mathrm{~m}$ above the ground, showing the glaucous leaf colour especially on the youngest leaves. B. Terrestrial habit, with the same morphology as that of reproductive individuals. C. Young infructescences with the green stylar layer, conspicuous basal sterile zone, and persistent subtending cataphylls. D. The base of the glaucous/pruinose petiole and persistent involute petiole sheath (arrow). E. Part of the petiole completely terete beyond the sheath. F. Leaf with two primary veins per lobe, sometimes bifid into lobules that divide up to $4 \mathrm{~cm}$ away from the costa (arrow). Photographs: M. Cedeño-Fonseca. 
cies, previously identified as M. pinnatipartita Schott, could represent a different, undescribed species.

\section{Distribution and habitat}

Monstera croatii is endemic to Costa Rica, where it is known only from the south on the Pacific side in the region of Golfito and the Parque Nacional Corcovado (both in the cantón of Golfito) at ca. 300-600 m, in primary and secondary forest and in open areas (Figure 6).

\section{Phenology}

Immature infructescences recorded in February; flowering observed in October and November.

\section{Conservation status}

Monstera croatii is protected in the Refugio Nacional de Vida Silvestre Golfito and in the Parque Nacional Corcovado.

\section{Notes}

Monstera croatii is differentiated from all other Costa Rican species of Monstera by having pruinose/glaucous stems and petioles, the petioles sheathing for about half their length, with the sheath wings involute and persistent and the free (distal) part terete or only weakly channeled. It is further differentiated by the deeply pinnatifid and bluish green leaf blades, sometimes with bifid lobes, and the pruinose peduncles with a persistent sheathing mucronate cataphyll.

A unique characteristic of this species is its terrestrial habit, reaching the adult vegetative stage in this state and climbing only to very limited height before flowering. Fertile terrestrial individuals were not found, but one plant was observed fertile after climbing only $50 \mathrm{~cm}$ above ground level with the same stem and leaf morphology as terrestrial examples.

Monstera croatii has sterile flowers with the ovary spherical, as is also the case in M. glaucescens Croat \& Grayum, which too has glaucous stems and briefly sheathed petioles, but that species (known only from the Caribbean side of Costa Rica) has the leaves pinnately lobed (never deeply pinnatifid), the petiolar sheath persistent but not with involute margins, and the non-sheathing part of the petiole channeled (never terete). Monstera croatii can also be confused with Monstera pinnatipartita, but that species has the petioles green or speckled (never glaucous), never develops to the adult vegetative form on the ground, is fertile only after significantly ascending its phorophyte, and has acuminate and marcescent (not mucronate and persistent) cataphylls.

\section{Additional specimens studied (Paratypes):}

COSTA RICA. Puntarenas, Golfito, Golfito, camino hacia las antenas, $8^{\circ} 38^{\prime} 55.1^{\prime \prime} \mathrm{N}, 83^{\circ} 9^{\prime} 30.8^{\prime \prime} \mathrm{W}, 389 \mathrm{~m}, 4$ February 2019 (fr.), M. Cedeño \& A. Hay 1625 (USJ [2 sheets]). Puntarenas, Golfito, Golfito, camino a las torres del I.C.E., aprox. $2 \mathrm{~km}$ antes de llegar, $8^{\circ} 39^{\prime} 25^{\prime \prime} \mathrm{N}$, $83^{\circ} 9^{\prime 2} 25^{\prime \prime} \mathrm{W}, 389$ m, 29 January 1992 (fr.), Á. Fernández 205 (CR, MO [3 sheets]). Puntarenas, Golfito, Parque Nacional Corcovado, Estación Agujas, Cerro Rincón, $8^{\circ} 31^{\prime} 34.467^{\prime \prime} \mathrm{N}, 83^{\circ} 28^{\prime} 3.9^{\prime \prime} \mathrm{W}, 600 \mathrm{~m}, 11$ November 1999 (fl.), E. Mora 725 (CR [2 sheets]).

Monstera gambensis M.Cedeño \& M.A.Blanco, sp. nov.

Type: Costa Rica, Puntarenas Province, Gol6to Canton, Gol6to, La Gamba, sendero sobre quebrada, $8^{\circ} 41^{\prime} 02^{\prime \prime} \mathrm{N}$, 83²'15”W, 94 m, 27 May 2016, M. Cedeño, A. P. Karremans \& I. Chinchilla 890 (holotype: USJ) (Figures 3, 4, 5).

\section{Diagnosis}

Monstera gambensis is recognised by its small entire leaves with or without fenestrations, and its asperous petioles with involute sheath margins that appear whitish. Similar in size to Monstera obliqua, it differs from that species by having asperous (vs. smooth) petioles, with the sheath margins persistent (vs. completely deciduous), and smaller leaf blades $(12-24 \times 5-10 \mathrm{~cm}$, vs. ca. $35 \times 14 \mathrm{~cm}$ ).

\section{Description}

Nomadic vines, fertile at ca. $2 \mathrm{~m}$ above the ground. Seedlings unknown. Juvenile plants appressed-climbing; stem dark green, slightly rough, internodes $3-5 \mathrm{~cm}$ long, 4-10 mm diam.; petioles visible (i.e., the leaves not shingling), dark green or light, slightly rough, $3-5 \mathrm{~cm}$ long, sheathed to the base of the geniculum, the wings persistent; leaf blades more or less horizontal, not flattened to the substrate of the phorophyte, $4-7 \times 3-4 \mathrm{~cm}$, obovate or lanceolate, subcordate to truncate at the base, acuminate at the apex, thinly coriaceous, without fenestrations. Adult plants appressed-climbing; stem terete, dark green, rough, internodes 1-4 cm long, 5-10 mm diam.; supporting roots black and corky, 4-6 cm long, feeder roots black and semi-corky, both with black root hairs; leaves numerous, sub-erect; petioles light green or whitish, rough to the geniculum, $17-22 \mathrm{~cm}$ long, sheathed to $2-3 \mathrm{~cm}$ below the base of the geniculum with the wings involute and persistent, the free portion slightly grooved; geniculum elongated, $0.5-1 \mathrm{~cm}$ long; leaf blades $12-24$ $\times 5-10 \mathrm{~cm}$, lanceolate, attenuate and decurrent on the 


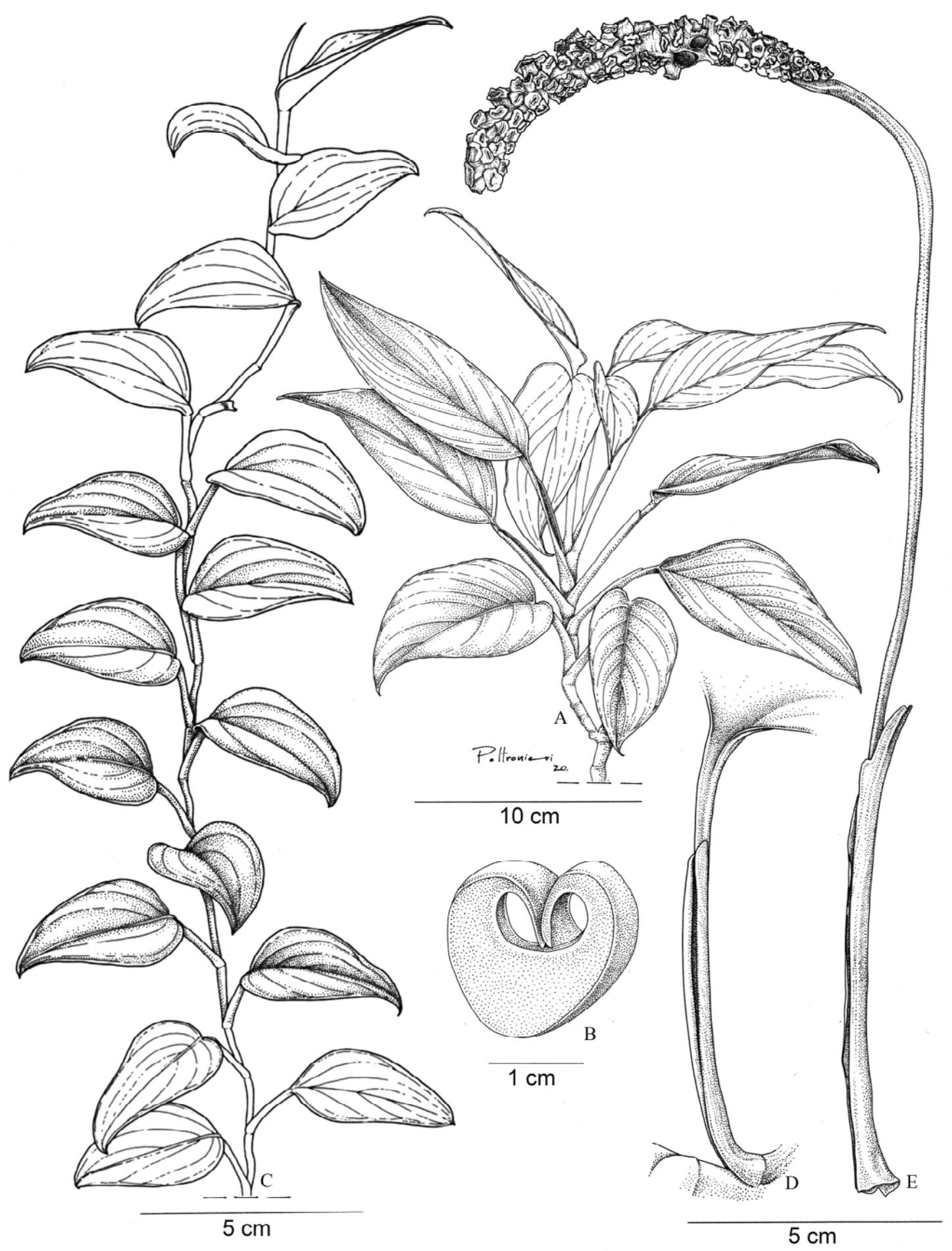

Figure 3. Monstera gambensis. A. Adult plant showing leaves without perforations. B. Cross-section of petiole showing involute sheath wings. C. Juvenile plant. D. Petiole of adult plant with persistent sheath and involute sheath wings. E. Mature infructescence with persistent cataphylls at the base. Illustration by Sara Díaz Poltronieri.

geniculum at the base (the decurrent part $0.5-1 \mathrm{~mm}$ wide), acuminate at the apex, without or (less commonly) with fenestrations (when present, one to two perfora- tions close to each other on the same side of the blade near its middle part), often only one side fenestrated, with entire margins, subcoriaceous; anterior costa chan- 

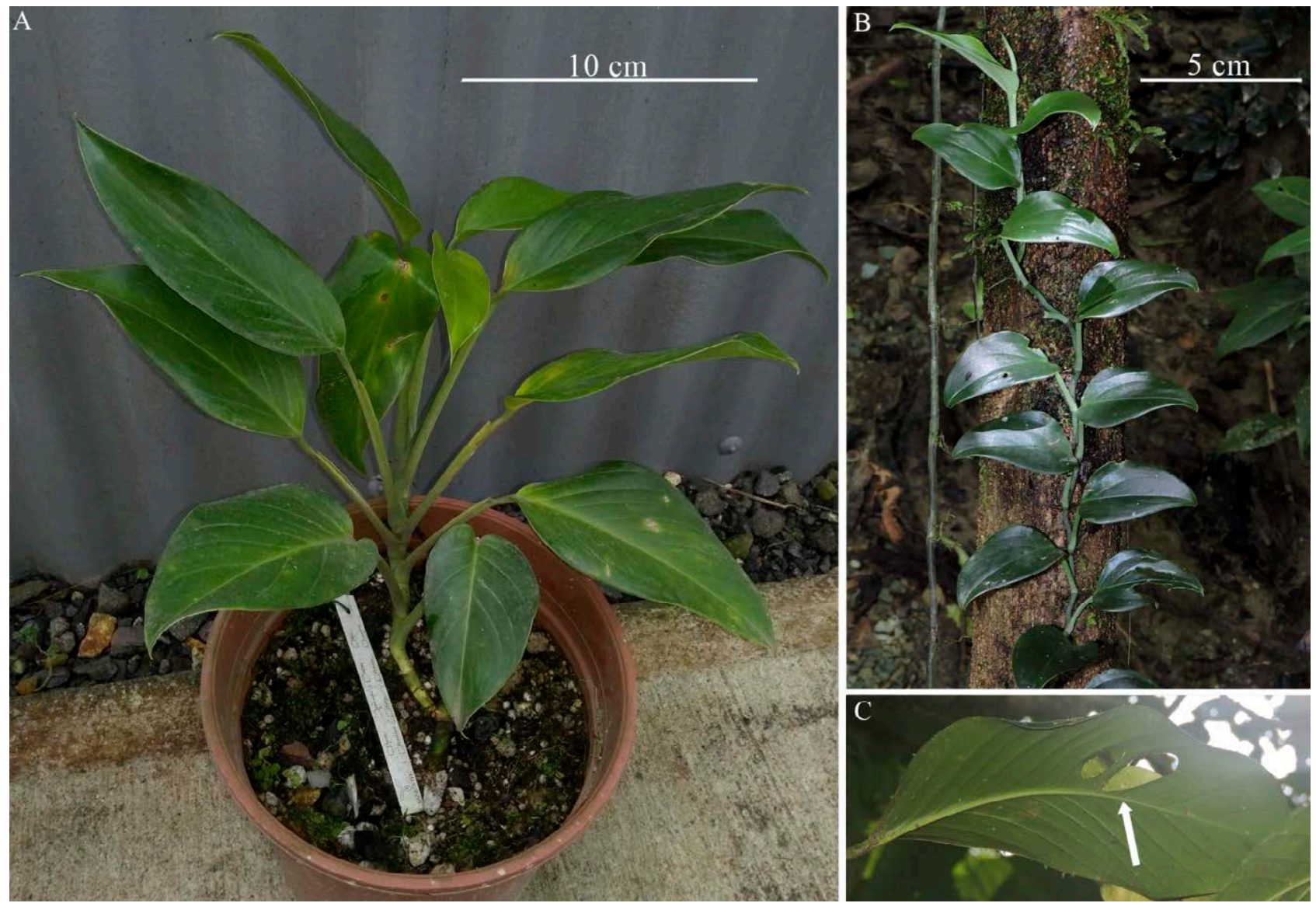

Figure 4. Monstera gambensis. A. Adult plant with non-perforated leaves. B. Juvenile plant. C. Adult leaf with two perforations. Photographs: M. Cedeño-Fonseca.

neled adaxially, convex to the middle of the blade abaxially, slightly rough, with $5-13$ primary lateral veins on each side, impressed or indistinct abaxially, prominent on the underside, collective vein not visible. Inflorescences on ascending stems; peduncle rough throughout, 20-25 cm long; spathe unknown; spadix 7-10 × 1.3-1.6 $\mathrm{cm}$, colour at and before anthesis unknown; sterile flowers 3-4 mm long; fertile flowers 4-5 $\mathrm{mm}$ long; stamens with laminar filaments 2-4 mm long; anther 1-2 mm long; ovary prismatic, longitudinally ribbed, $2-3 \times 2-3$ $\mathrm{mm}$; stylar region hexagonal, $1-2 \times 3-5 \mathrm{~mm}$; stigma linear. Infructescence yellow when ripe; fruits with white pulp; seeds black, 2-3 $\mathrm{mm}$ long.

\section{Etymology}

The epithet gambensis refers to the type locality.

\section{Distribution and habitat}

Monstera gambensis is endemic to Costa Rica, where it has been found growing low on the supporting trees (ca.
$2 \mathrm{~m}$ above ground level), in rain forest at La Gamba Biological Station, cantón Golfito, mostly at 50-100 m. (Figure 6).

\section{Phenology}

Flowering has not been observed. An infructescence was recorded in May.

\section{Conservation status}

It is protected at the La Gamba Biological Station, the only known locality for this species.

Notes

Monstera obliqua, a species whose type is from Surinam and which in its current, broad conception extends into Amazonia, is known in Costa Rica only from the southeastern corner of the country (Grayum 2003), while the Costa Rican endemic M. gambensis is known only by a single collection from La Gamba, Golfito. Monstera gambensis is one of the smallest species in the genus, 

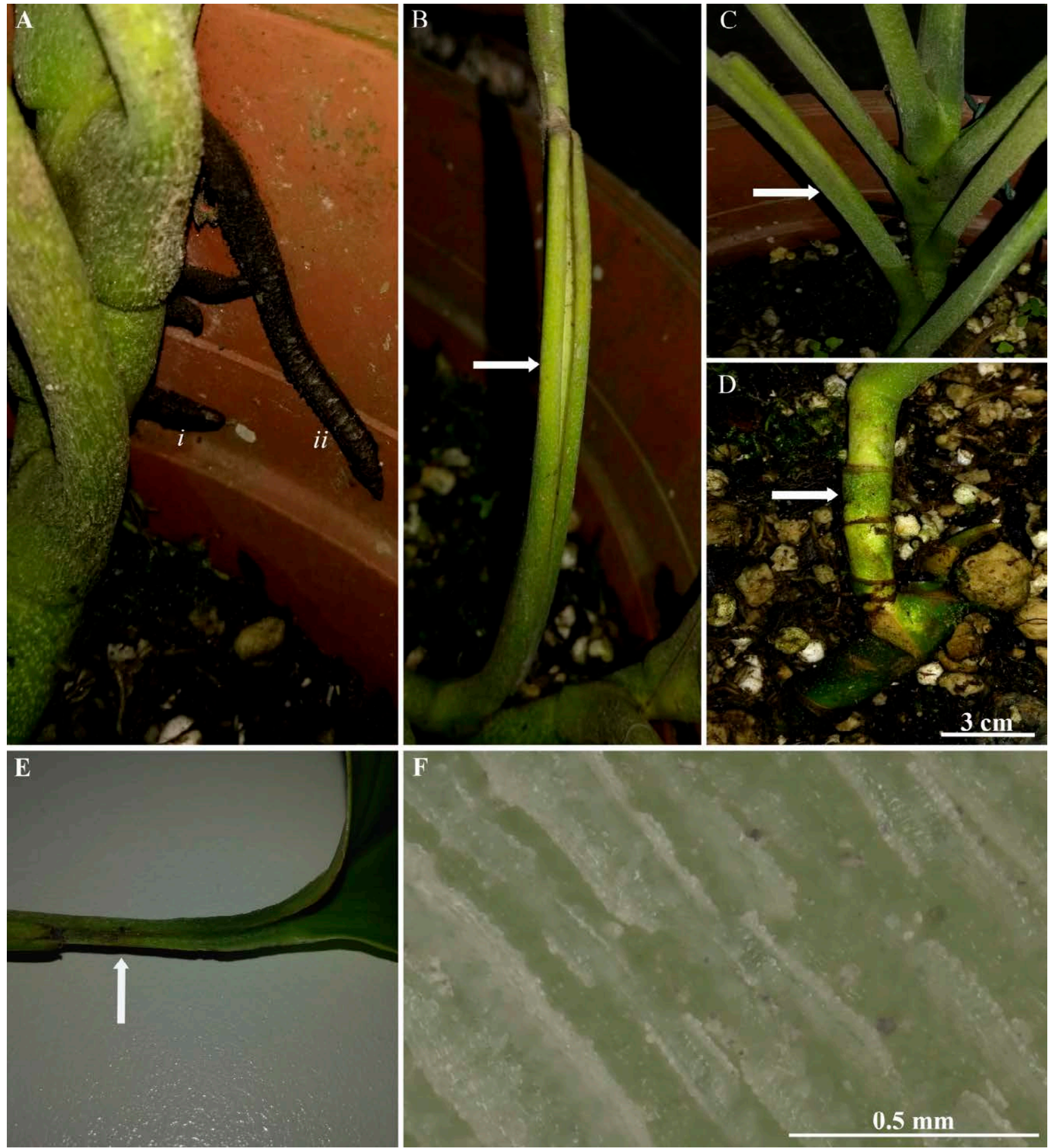

Figure 5. Monstera gambensis. A. Support roots (i) and a feeding root (ii) both corky and blackened. B. Petiole sheath margins persistent and involute in adult plants (arrow). C. Petioles with sheath margins persisting, whitish and asperous (arrow). D. Internodes of adult plant (arrow). E. The shallowly channeled distal portion of the petiole (arrow). F. Portions of either dead epidermis or epicuticular waxes that give a whitish appearance and an asperous texture to the surface of the petioles. Photographs: M. Cedeño-Fonseca.

together with . obliqua and M. minima. The latter, with smaller petioles $(2-6 \mathrm{~cm})$, leaf blades $(9-14 \times 2-4$ $\mathrm{cm}$ ), and spadices (ca. $4.4 \times 09-1 \mathrm{~cm}$ ) even smaller than those of M. gambensis (Jácome \& Croat 2002), is only known from the northern (Caribbean) coast of Panama and along the Pacific slope of northern Colombia, in the 


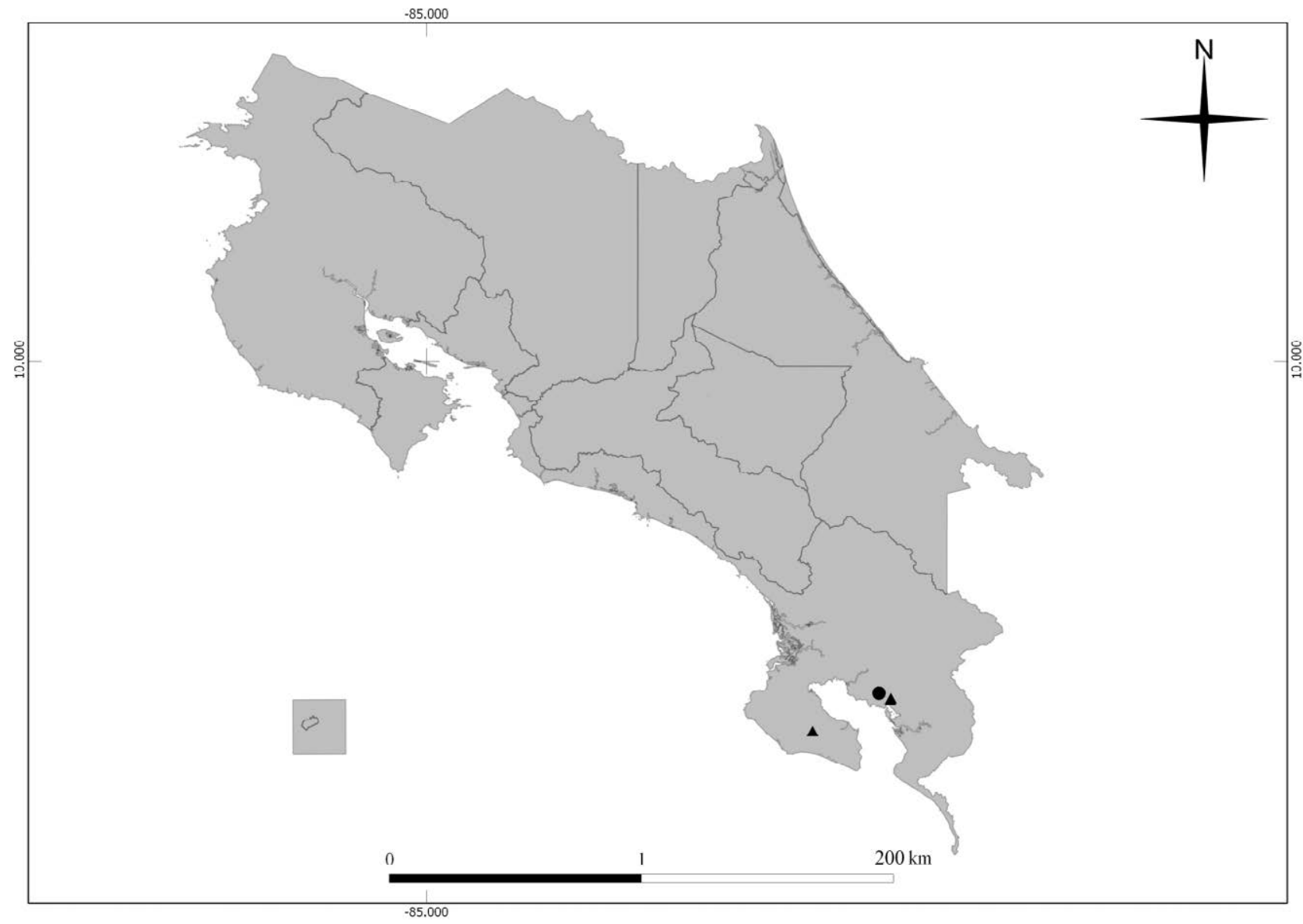

Figure 6. Distribution of Monstera croatii (triangles), in Golfito and Corcovado National Park, and M. gambensis (circle), in Golfito, Costa Rica.

Chocó region (Jácome and Croat 2002). In Costa Rica, M. gambensis is found in lowland tropical wet forest at elevations of up to ca. $100 \mathrm{~m}$. The individuals observed were climbing in the undisturbed forest on small trees no more than $2.5 \mathrm{~m}$ high, with abundant shade in the understorey.

Most adult leaves of Monstera gambensis are not fenestrated, but occasionally leaves are produced with up to two perforations, close to each other on the same side of the blade near its middle part. The measurements for the flowers of $M$. gambensis given above were taken from flower remnants of a single fruiting spadix, so they should be interpreted with caution.

\section{ACKNOWLEDGMENTS}

Marco Cedeño-Fonseca thanks the Organization for Tropical Studies for a Glaxo-Wellcome research grant and the Rexford Daubenmire fellowship, which supported fieldwork for the project "Taxonomy of the genus Monstera (Alismatales: Araceae) for Costa Rica”, and an Alwyn H. Gentry Fellowship from the Missouri Botanical Garden and a Mini-ARTS Fellowship from the Society of Systematic Biologists, which allowed him to study herbarium material at the Missouri Botanical Garden, the Marie Selby Botanical Gardens, and the New York Botanical Garden. Michael Mittermeier, Cristina Goettsch Mittermeier, and Caroline Sparks also helped in raising funds for travel through a Gofundme.com campaign. Director Adam Karremans and the staff at the Jardín Botánico Lankester of Universidad de Costa Rica are thanked for allowing the cultivation of living plants. Isler Chinchilla and Gustavo Rojas-Alvarado are thanked for their help in the field. Two anonymous reviewers are thanked for their insightful suggestions that greatly improved the manuscript. We are grateful to the Ministerio de Ambiente y Energía de Costa Rica (MINAE) and its Sistema Nacional de Áreas de Conservación (SINAC) for issu- 
ing the scientific permits under which wild specimens were collected. This contribution represents part of the Master's thesis of Marco Cedeño-Fonseca, completed in the Programa de Posgrado en Biología at Universidad de Costa Rica.

\section{REFERENCES}

Cedeño-Fonseca MV. 2019. Revisión taxonómica del género Monstera (Araceae) en Costa Rica. Unpublished M.Sc. thesis, Programa de Posgrado en Biología, Sistema de Estudios de Posgrado, Universidad de Costa Rica, San José, Costa Rica.

Cedeño-Fonseca M, Karremans AP, Ortíz OO. 2018. Monstera limitaris (Araceae), a new species from the border between Costa Rica and Panama. Phytotaxa 376: 37-42.

Croat TB. 1992. Species diversity of Araceae in Colombia: a preliminary survey. Ann. Missouri Bot. Gard. 79: 17-28.

Croat TB, Krömer T, Acebey A. 2010. Monstera florescanoana (Araceae), a new species from central Veracruz, Mexico. Revista Mex. Biodivers. 81: 225-228.

Grayum MH. 2003. Araceae. Pp. 59-200 in, Hammel BE, Grayum MH, Herrera C, Zamora N, editors. Manual de Plantas de Costa Rica. Volumen II: Gimnospermas y Monocotiledóneas (Agavaceae-Musaceae). Monogr. Syst. Bot. Missouri Bot. Gard. 92: 1-694.

Hay A. 2019. Durianology, discovery, and saltation: the evolution of aroids. Gard. Bull. Singapore 71 (Suppl. 2): $257-313$.

Jácome J, Croat TB. 2002. Notes on Monstera minima Madison (Araceae) in Colombia and Panama. Aroideana 25: 60-62.

Madison M. 1977. A revision of Monstera (Araceae). Contr. Gray Herb. 207: 3-100.

Mayo SJ, Bogner J, Boyce PC. 1997. The genera of Araceae. Kew (UK): Royal Botanic Gardens.

Ortiz OO, Croat TB, Baldini RM. 2018. Current status of aroid species diversity in Panama, including new records for the country. Webbia 73:141-153.

Tam SM, Boyce PC, Upson TM, Barabé D, Bruneau A, Forest F, Parker JS. 2004. Intergeneric and infrafamilial phylogeny of subfamily Monsteroideae (Araceae) revealed by chloroplast trnL-F sequences. Amer. J. Bot. 91: 490-498.

Zotz, G. 2013. 'Hemiepiphyte': a confusing term and its history. Ann. Bot. (Oxford) 111: 1015-1020.

Zuluaga A, Llano M, Cameron K. 2019. Systematics, biogeography and morphological character evolution of the hemiepiphytic subfamily Monsteroideae (Araceae). Ann. Missouri Bot. Gard. 104: 33-48. 